DOI: https://doi.org/10.24867/07BE19Adamovic

\title{
КОМУНИКАЦИОНИ ПРОТОКОЛИ У АУТОМОБИЛСКОЈ ИНДУСТРИЈИ И АУТОМАТИЗАЦИЈИ
}

\section{COMMUNICATION PROTOCOLS IN AUTOMOTIVE INDUSTRY AND AUTOMATION}

Милош Адамовић, Факултет теничких наука, Нови Сад

\begin{abstract}
Област - ЕЛЕКТРОТЕХНИКА И РАЧУНАРСТВО
Кратак садржај - Предмет овог рада су најчешће коришћени комуникациони протоколи у аутомобилској индустрији и аутоматизащији. Прво ће бити дат кратак историјат развоја аутомобилске индустрије као и електричних и електронских система који се користе у управљању. Од посебног значаја за рад јесу CAN, LIN и CANopen протоколи који су детаљно описано уз примере юихове примене у возилима и индустрији. На самом крају извршиће се поређење поменутих, дати одређене предности и мане, као и могућност даљег развоја и унапређења.
\end{abstract}

Кључне речи: Аутомобилска индустија, CAN y аутоматизацији, Комуникаџиони протоколи

\begin{abstract}
The subject of this study is an analysis of the communication protocols in automotive industry and automation. First of all brief history of the development of the automotive industry as well as the electrical and electronic systems used in control will be given. The major importance for study are communication protocols CAN, LIN, CANopen which are detaile described with examples for every each. On the end comparison between mention communication protocols with advantages and disadvantages and as well as the possibility of further development and improvement will be made.
\end{abstract}

Keywords: Automotive industry, CAN in Automation, Communication protocols

\section{1. УВОД}

Услед изузетно брзог развоја аутомобилске електронике, комплексности система који се у данашње време уграђују у савремене аутомобиле, као и због великог броја различитих ECU јединица које се користе за управљање тим системима постоје потребе за што бржим, ефикаснијим, сигурнијим преносом података између истих.

Потребан је рад у реалном времену и нема простора за грешке приликом рада. Предмет овог рада представља опис и примену различитих комуникационих протокола у аутомобилској индустирији и аутоматизацији. Посебан осврт ће бити на употребу CAN протокола у аутомобилској индустрији као и његова широка примена у аутоматизацији.

\section{НАПОМЕНА:}

Овај рад проистекао је из мастер рада чији ментор је био др Дарко Марчетић, ред. проф.

\section{2. АУТОМОБИЛСКА ИНДУСТРИЈА}

Развој аутомобила какве данас познајемо је почео 1885. године. Познати конструктори су се утркивали ко ће направити бољи патенат и увести неку новину што је и данас случај.

Руку под руку са развојем СУС мотора је ишао и развој електричних, а касније и електронских система. Прва електрична светла у возилима су уграђена 1908. године, а постају стандардни део опреме 1920. године.

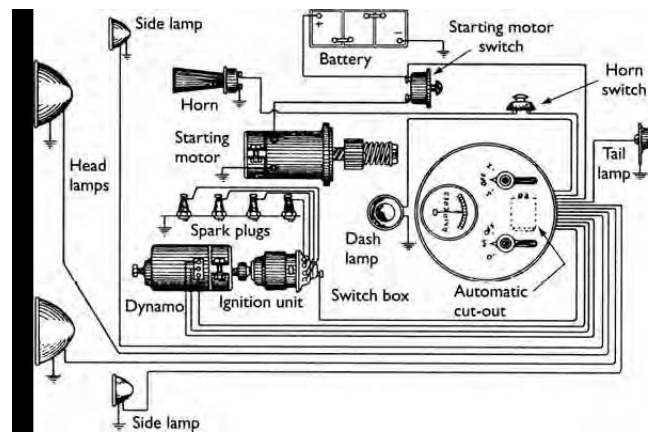

Слика 1.1. Комплетна електрична шема типичног аутомобила из '30. година ХХ века

Најранији елекртични системи коришћени у возилима су се појавили почетком XX века и након Другог светског рата долази до наглог развоја и примене електронике у аутомобилској индустрији да би се дошло до електричних система који се налазе на хибридним возилима и електричним аутомобилима. Системима на данашњим возилима управљају моћне ECU контролне јединице.

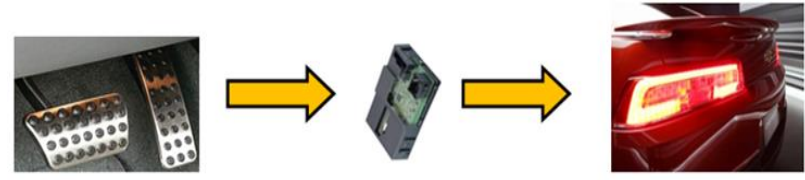

Слика 1.2. Пример једноставног управљања које врши ЕСU контролна јединица.

\section{3. КОМУНИКАЦИОНИ ПРОТОКОЛИ}

Као што је наглашено у уводу, комуникациони протоколи који се користе у аутомобилској индустрији треба да задовоље специфичне карактеристике преноса података..

У зависности од класе у којој се налазе, модерна возила могу да имају преко стотину ECU контролих јединица. Данас најзаступљенији комуникациони протоколи који се користе у савременим возилима су 
CAN, LIN, MOST као и FlexRay, Ethernet који се користе у моћнијим системима где се захтева велика брзина и проток информација.
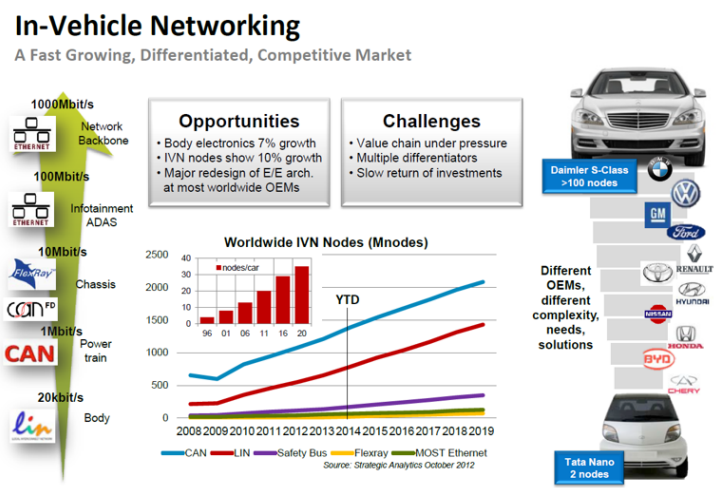

Слика 3.2 Примена комуникационих протокола у савременим возилима

CAN протокол са својим разним побољшаним варијатама као нпр. CAN FD је тренутно најзаступљенији у аутомобилској индустири. Свакако један од најбитнијих је LIN протокол користи се на оним местима у контролном систему возила где брзина преноса није критична. MOST протокол је прилагођен за мултимедију возила. FlexRay je протокол који има изразито боље карактеристике од CAN протокола и у будућноси ће га сигурно заменити. Ethernet протокол је такође заступљен управо због све више компликованијих за управљање и све више заступљенијих система који треба да обезбеде аутономну вожњу као што је ADAS систем.

\subsection{CAN протокол}

Robert Bosch GmbH je 1982. године увео „CAN bus“ и тако заменио дотадашњу комуникацију увођењем јединствене магистрале. Први аутомобил који је поседовао CAN магистралу и који је ушао у масовну производњу био је Mercedes-Benz S-Class из 1991. године. На обједињеној магистрали је комуницирало 5 ECU контролних модула. ISO (International Organization for Standardization) је 1993. године је прихватио CAN протокол кака стандард ISO 11898.

CAN je асинхрона „multi-master“ i ,bidirectional half duplex“ серијска магистрала која је реализована помоћу пара уплетених жица и раздвојена отпорником различитих отпорности зависно од конкретног стандарда. Магистралу чине два или више чворова прикључених на линеарну мрежу.

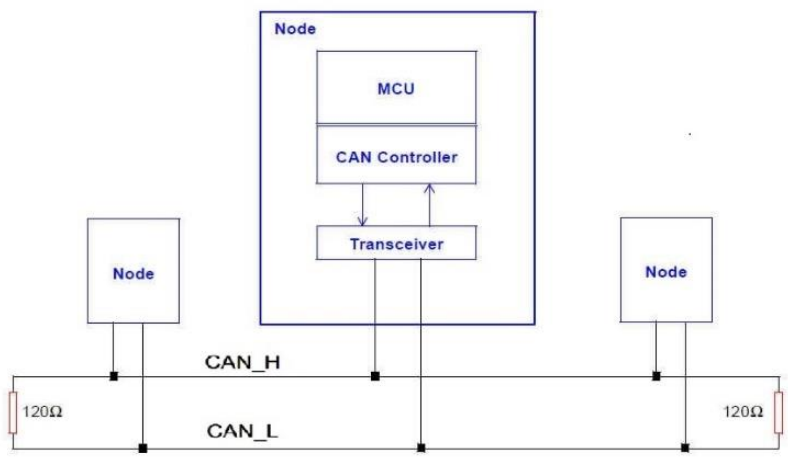

Слика 3.1.1. Шематски приказ САN чворова на магистрали (Node-ECU контролна јединице)
Возило може да поседује две или више CAN мрежа које раде на различитим брзинама. У зависности од потребе за брзином постоје Low-speed CAN и Higherspeed CAN.

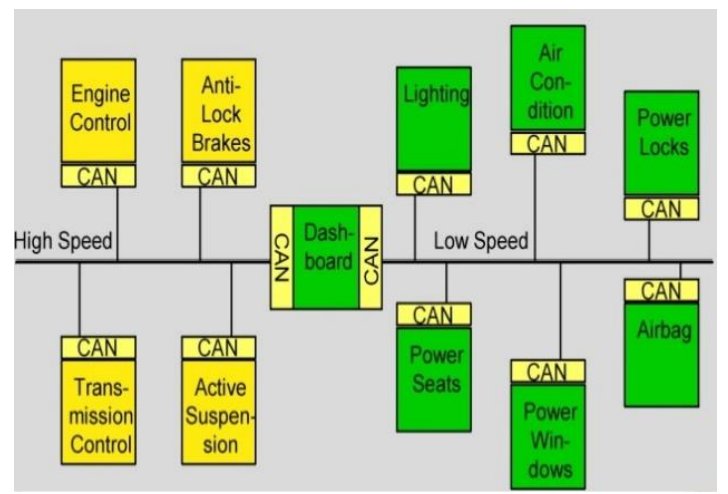

Слика 3.1.2. Пример умрежавања електронских компоненти у возилу применом CAN магистрале

Модули у случају CAN протокола комуницирају тако што користе две одвојене жице за комуникацију, те жице се називају CAN H (од „CAN High“) i CAN L (од „CAN Low“), види слику 3.1.1. Пошто се комуникација ослања на напонску разлику између две магистралне линије, CAN сабирница није осетљив на индуктивне скокове,друга електрична поља или друге сметње. То чини CAN магистралу поузданим избором за мрежну комуникацију у системима који су потребни на возилима, као и у осталим индустријским системима.

Како је већ поменуто CAN протокол је асинхрона „multi-master“ мрежа заснована на порукама где сваки чвор има могућност да шаље и прима поруке. Да не би дошло до колизије на магистрали постоје правила по којима предност имају оне поруке које су вишег приоритета и због тога је дефинисано да на једној мрежи сваки чвор мора да има скуп порука које може да шаље.

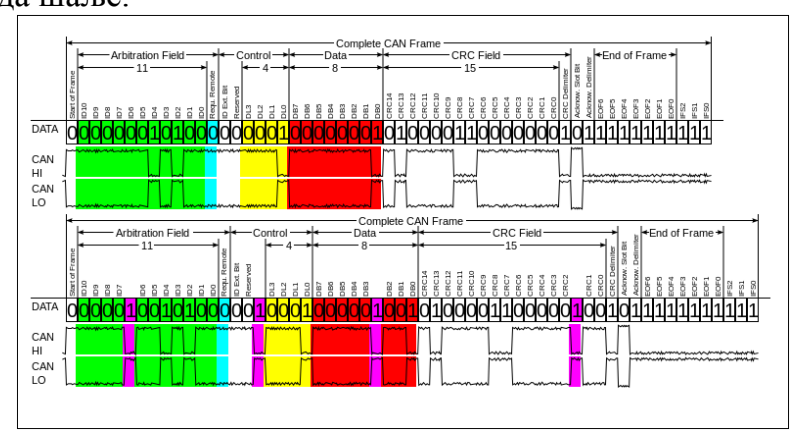

Слика 3.1.2.3. Порука у основном формату са приказаним електричним нивоима

\subsection{CANopen протокол}

Индустријске магистрале у индустријским мрежама се користе за повезивање „Field“ уређаја. Такве мреже cy: ProfiBus, PROFInet, Modbus, Ethernet и многе друге, али оне нису предмет овог рада већ употреба CAN протокола у комбинацији са поменутим. Као што је написано поред „Fieldbus“ постоје и мреже засноване на CAN протоколу које чине основни CAN и виши CAN протоколи у које спада и CANopen. 
CANOpen магистрала је у већини случајева имплементирана у оквиру неког великог система и одговарајућим „gateway“ уређајима повезана са остатком тог великог система.

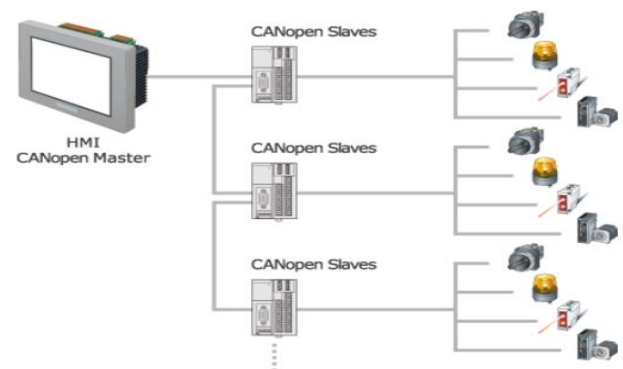

Слика 3.1.4.1. Приказ примене CANopen протокола у индустријском управљању

CANopen омогућава 127 чворова на магистрали , док је избор могућих брзина преноса података далеко већи. На мрежи мора постојати бар два чвора од којих у сваком тренутку један мора бити „Master“, а други , Slave“.

CANopen протокол врши сегментацију великих порука у 8-битне пакете и шаље их пакет по пакет у оквиру поруке дужине 111 битова. То омогућава да порука вишег приоритета увек прекине пренос велике поруке.CANopen уређаји у подржани са сервисом за администрирање на мрежи помоћу CANopen network management (NMT) slave state machine и она дефинише начин комуникације између урађаја на мрежи.

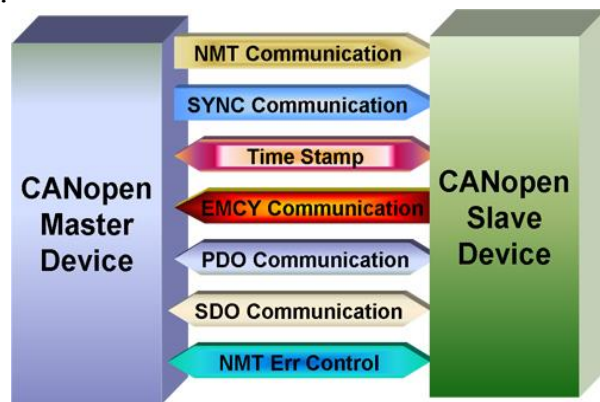

Слика 3.1.4.2. Приказ CANopen комуникащије

\subsection{LIN протокол}

LIN мрежа се у аутомобилској индустрији користи као подмрежа CAN мреже, а може и независно да буде директно повезана на главни рачунар возила. Такође постоје одређени „Gateway“ уређаји који могу један протокол да прилагоде другом.

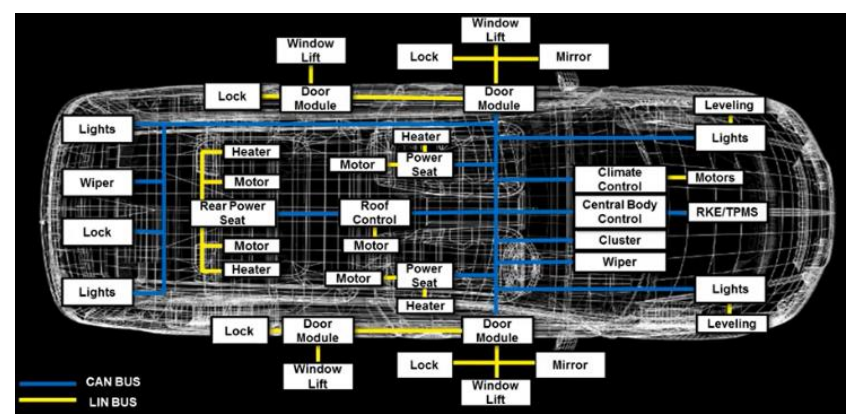

Слика 3.2.2. Приказ LIN протокола у савременим аутомобилима
LIN магистрала користи једну жицу за комуникацију и у оквиру LIN протокола постоји само један „Master“ и до 15 „Slave“ уређаја. Пренос података је синхрони и максималном брзином од 20Kbit/s. Физички ниво LIN протокола је заснован на стандарду ISO $9141 \mathrm{ca}$ неким модификацијама за возила. У данашњим топологијама умрежавања користе се микроконтролери који имају или UART могућност или намјенски LIN хардвер.

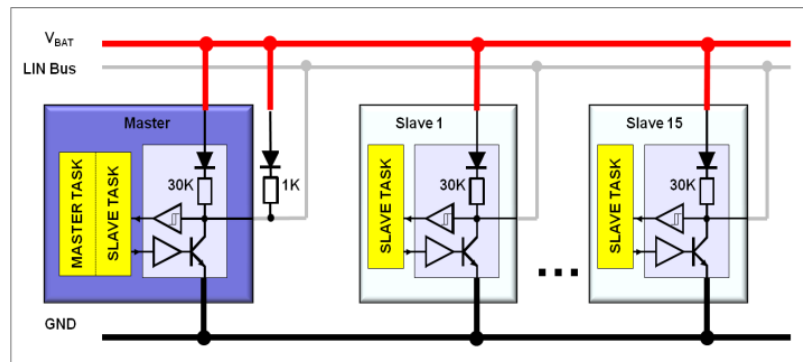

Слика 3.2.1.1. Шематски приказ физичког нивоа LIN магистрале

„Master“ и „Slave“ уређаји у свакој њиховој поруци помоћу примопредајника који претвара бит логике из микроконтролера у више напонске нивое и на тај начин формира поруку која је препознатљива свима на магистрали.

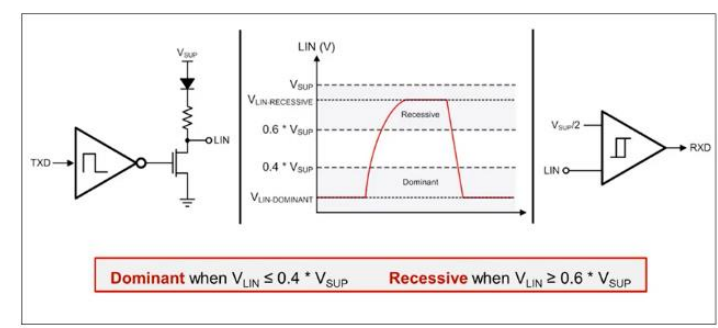

\section{Слика 3.2.1.2. Вредности напона LIN магистрале} приликом примања и слања битова

Све поруке на магистрали контролише „Master“ тако што шаље и захтева поруке које у себи садрже заглавље поруке (Message Header) и део поруке са одговором (Message Response).). Одговор креирају , Slave“ уређаји који су прозвани, али може и сам „Master“ уколико је то потребно да пошаље одређене податке осталим уређајима.

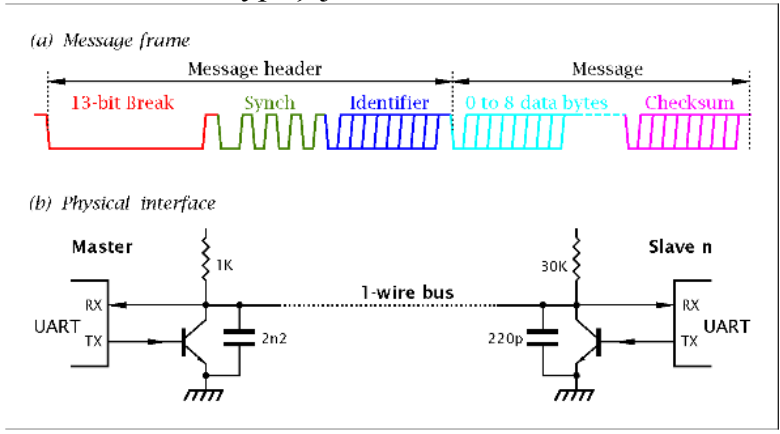

Слика 3.2.2.1. Приказ физичке архитектуре и изгледа LIN поруке која се шаље на магистралу 


\section{3. Кратак преглед и основне особине} комуникационих протокола који су тема овог рада

Како је већ наглашено, различити комуникациони протоколи се користе у различитим системима и на различитим деловима тог система.

Одлуку где ће се користити који протокол углавном доносе произвођачи у складу са потребама система и финансијским могућностима.

\begin{tabular}{|c|c|c|c|c|c|}
\hline $\begin{array}{c}\text { Тип } \\
\text { магистрале }\end{array}$ & CAN & LIN & Flexray & MOST & Ethernet \\
\hline $\begin{array}{l}\text { Брзина } \\
\text { преноса }\end{array}$ & $1 \mathrm{Mbit} / \mathrm{s}$ & $20 \mathrm{Kbit} / \mathrm{s}$ & $10 \mathrm{Mbit} / \mathrm{s}$ & $24 \mathrm{Mbit} / \mathrm{s}$ & $10 \mathrm{Gbit} / \mathrm{s}$ \\
\hline Повезивање & 2 жице & 1 жице & $\begin{array}{l}2 \text { i } 4 \text { жице, } \\
\text { оптички } \\
\text { кабел }\end{array}$ & $\begin{array}{l}\text { опиички } \\
\text { кабел }\end{array}$ & 2 жице \\
\hline Архитектура & $\begin{array}{l}\text { Multi- } \\
\text { Master, до } \\
64 \text { чвора }\end{array}$ & $\begin{array}{l}\text { Single- } \\
\text { Master , до } \\
16 \text { чвора }\end{array}$ & $\begin{array}{l}\text { Multi-Master } \\
\text { до } 64 \text { чвора }\end{array}$ & $\begin{array}{l}\text { Multi-Master } \\
\text {,до } 64 \text { чвора }\end{array}$ & $\begin{array}{l}\text { Multi-Master, } \\
\text { неораничен } \\
\text { број }\end{array}$ \\
\hline $\begin{array}{l}\text { Начин } \\
\text { комуникациј } \\
\text { e }\end{array}$ & Асинхрони & Синхрони & $\begin{array}{l}\text { Асинхрони и } \\
\text { Синхрони }\end{array}$ & $\begin{array}{l}\text { Асинхрони и } \\
\text { Синхрони }\end{array}$ & Синхрони \\
\hline Надоградња & могућа & мoryћa & могућа & могућа & могућа \\
\hline Употреба & $\begin{array}{l}\text { Контрола } \\
\text { мотора и } \\
\text { конфора }\end{array}$ & Конфор & $\begin{array}{l}\text { Контрола } \\
\text { мотора и } \\
\text { сигурности }\end{array}$ & $\begin{array}{l}\text { CD и DVD, } \\
\text { GPS } \\
\text { навигација }\end{array}$ & $\begin{array}{l}360^{\circ} \text { камера и } \\
\text { мултимедија }\end{array}$ \\
\hline Cena & srednja & niska & visoka & srednja & visoka \\
\hline
\end{tabular}

Табела 3.3.1. Приказ поређења комуникационих поротокола у аутомобилској индустрији

\section{4. МОДЕРНИ СИСТЕМИ НА ВОЗИЛИМА И СПЕЦИЈАЛНИ ЗАХТЕВИ}

Опрема у возилу се с временом развила тако да укључује разне аутомобилске системе нове генерације који захтевају специјалну повезаност, попут напредног система аутономне вожње и помоћи возачу - advanced driver assistance systems (ADAS) и многи други.

Ови системи брзо постају стандардна опрема на многим возилима данашњице.

Поред тога, услед страховитог пораста истраживања и развоја аутономних возила, електронска опрема има задатак да испоручује сигнале велике брзине, велике пропусности и велике снаге за управљање тим системима.

Такође захтева се да комуникациони протоколи у овим системима испуне све задатке који се стављају пред њих велика брзина, велика пропусна моћ локалне мреже као и у новије време потребе за комуникациом са спољним светом, GPS-ом, осталим возилима у околини и саобраћајним системима

\section{5. ЗАКЉУЧАК}

Моторна возила последњих година су кренула вртоглаво да се развијају. Сам управљачки систем мора да одговори на све веће захтеве. Комплексност система диктира цену возила и произвођачи истих се боре да смање цену производње, како би били конкурентни на тржишту.

У системима данашњих возила да би била задовељена функционалност и безбедност потребни су комуникациони протоколи који ће на ефикасан и брз начин повезати цео систем. Рад у реалном времену је захтев број један који треба испунити. Комуникациони протоколи који контролишу пренос података морају да имају велику пропусну моћ и брзину преноса података.

\section{6. ЛИТЕРАТУРА}

[1] Tom Denton, Automobile Electrical and Electronic Systems, Elsevier Butterworth-Heinemann, 2004

[2] Dr. Wilrid Dubitzky, Turgut Karacay, "CAN - From its early days ", CAN Newsletter, 1/2013

[3] J. Lee, K. Choi, and J. Lee, "Collecting Big Data from Automotive ECUs beyond the CAN Bandwidth for Fault Visualization", Hindawi Mobile Information Systems Volume 2017, Article ID 4395070, 13 pages, 27 February 2017

[4] Марчетић,,Микропрочесорско управљане енергетским управљачима" ФТН Издаваштво, Нови Сад, Србија

[5] Веб cajm: https://www.automatika.rs/bazaznanja/obrada-signala/canopen-visi-canprotokol.html

[6] Веб cajm: $\quad$ https://www.can-cia.org/canknowledge/can/systemdesign-can-physicallayer/

\section{Kratka biografija:}

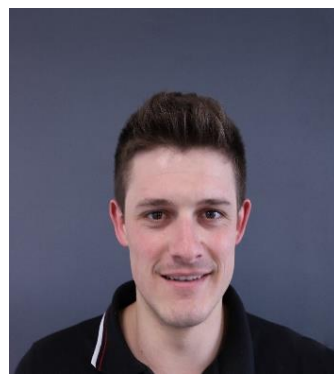

Милош Адамовић рођен је у Београду, Република Србија 17.4.1993. Године. Мастер рад на Факултету техничких наука из области Електротехнике и рачунарства - Енергетска електроника и електричне машине одбранио је 2019. године. Контакт:adamovicmilos993@gmail com 